This is an Accepted Manuscript of an article published by Taylor \& Francis in International journal of science education on 23 Oct 2019, available online: http://www.tandfonline.com/doi/

full/10.1080/09500693.2019.1679906

\title{
The influence of fieldwork design on student perceptions of skills development during field courses
}

\author{
Emma L. Peasland ${ }^{a^{*}}$, Dominic C. Henri ${ }^{\mathrm{a}}$, Lesley J. Morrell ${ }^{\mathrm{a}}$ and Graham W. \\ Scott ${ }^{\mathrm{a}}$ \\ ${ }^{a}$ Department of Biological and Marine Sciences, University of Hull, Hull, UK \\ Department of Biological and Marine Sciences, Hardy Building, University of Hull, \\ Cottingham Road, HU6 7RX. e.peasland@2016.hull.ac.uk
}

ORCID ID:

EL Peasland: orcid.org/0000-0002-3001-5671

DC Henri: orcid.org/0000-0002-7574-5846

LJ Morrell: orcid.org/0000-0003-0256-7871

GW Scott: orcid.org/0000-0003-0896-0287

Emma Peasland is a research student in the Department of Biological and Marine Sciences at the University of Hull. Her current research investigates the benefits of fieldwork learning with a focus on graduate employability.

Dominic Henri is Director of Student Experience for the Department of Biological and Marine Sciences at the University of Hull. He is a Senior Fellow of the Higher Education Academy.

Lesley Morrell is Director of Studies for the Department of Biological and Marine Sciences at the University of Hull. She is a Senior Fellow of the Higher Education Academy.

Graham Scott is Professor of Bioscience Education at the University of Hull. He is a National Teaching Fellow and a Principal Fellow of the Higher Education Academy.

Word Count: 9482 


\section{The influence of fieldwork design on student perceptions of skills development during field courses}

Employability is a key issue for students and Higher Education Institutions and a key component of employability is possessing the skills a role requires. In the environmental sciences, fieldwork has been shown to provide an opportunity for students to develop employability-enhancing technical and transferable skills. However, students can have difficulty identifying the transferable skills they develop both during fieldwork and throughout their degree programmes. We investigated whether different pedagogical approaches to fieldwork (in which staff or students design the field investigations) influenced the skills that students developed and identified. Additionally, we explored whether students recognised that skills developed during fieldwork might enhance their employability, which was previously unclear. Collecting data daily throughout three residential field courses provided a novel approach to assessing student perceptions of skills development through fieldwork as much previous research has focused on post-course data collection. Overall, students recognised technical skills more frequently than transferable skills and were able to link their skills development to their future employability. However, when fieldwork investigations were staff-led, students recognised more technical skills, but when students designed their fieldwork investigations themselves they recognised more transferable skills. We suggest that to maximise the skills development benefits of fieldwork, field courses should include a variety of fieldwork teaching designs to allow students to develop the widest array of skills possible. Additionally, students should be encouraged to reflect on their experiences throughout a field course as reflection is thought to aid their ability to recognise how their skills have developed.

Keywords: fieldwork; biology education; ecology education; employability; skills; field trips; higher education 


\section{Employability and higher education}

Employability is an important issue for students and Higher Education Institutions (Artess, Hooley \& Mellors-Bourne, 2017; Furnell \& Scott, 2015; Sarkar, Overton, Thompson \& Rayner, 2016; Saunders \& Zuzel, 2010; Sin \& Amaral, 2017). In the UK, this is highlighted by the inclusion of employability in Quality Assurance Agency (QAA) subject benchmark statements (e.g. QAA, 2014a; QAA, 2014b, 2015) and the use of graduate employment outcomes in university league tables (e.g. Complete University Guide, 2018; The Guardian, 2018) and the recently introduced Teaching Excellence Framework (Department for Education, 2017). Internationally, interventions such as the Bologna Process in Europe (Sin \& Amaral, 2017; Wall \& Speake, 2012), and government reports and guidelines including those in Australia (Bennett, Richardson \& MacKinnon, 2016) and China (Wang, Zhang, Liu \& Lai, 2012) demonstrate similar importance. Furthermore, increasing their employability is suggested to be a key motivation for students entering higher education (Artess et al., 2017; Furnell \& Scott, 2015; McCune, Hounsell, Christie, Cree \& Tett, 2010; Tavares, 2017). As it relates specifically to higher education, we use the definition of employability provided by Yorke (2006:8):

a set of achievements - skills, understandings and personal attributes - that make graduates more likely to gain employment and be successful in their chosen occupations, which benefits themselves, the workforce, the community and the economy.

Key to this definition is that to be employable one must possess the necessary skills, understandings and personal attributes that a chosen role requires. Understandings comprise subject-specific knowledge (Yorke, 2006), and Tymon (2013) suggests that skills must be employed to 'do something' and can be developed or acquired, whilst personal attributes are qualities related to individuals’ psychology and personality. These may be inherited and, as such, personal attributes may be more difficult, or impossible, to develop (Tymon, 2013). In 
this paper, we consider the development of skills and their relationship to employability in the context of learning through fieldwork. We do not directly consider knowledge or personal attributes but we do acknowledge that both may be developed through fieldwork (Larsen, Walsh, Almond \& Myers, 2017; Scott et al., 2012; Stokes \& Boyle, 2009).

\section{Fieldwork and skills development}

For students following programmes in the biosciences, environmental sciences or geographical and earth sciences, fieldwork presents an opportunity to develop employabilityenhancing skills (Kent, Gilbertson \& Hunt, 1997; Mauchline, Peacock \& Park, 2013; Scott et al., 2012; Wall \& Speake, 2012). Boyle et al. (2007, p. 300) define fieldwork as "any component of the curriculum that involves leaving the classroom and learning through firsthand experience”, which indicates the potential diversity of 'the field'. Indeed, the field could include towns, tourist attractions or organisations, however, we focus on fieldwork undertaken outdoors in natural environments. Well-designed laboratory or digital practical work, lectures or written assignments can also develop students’ skills (QAA, 2015) though this research considers the opportunities for skills development provided specifically by fieldwork.

The skills that fieldwork might develop are often grouped into three categories: technical, transferable and personal development (Goulder, Scott \& Scott, 2012; Hovorka \& Wolf, 2009; Kent et al., 1997; Wall \& Speake, 2012). Technical skills are subject or rolespecific; for example, geologic mapping in geology (Stokes \& Boyle, 2009) or taxonomic identification in biology (Maw, Mauchline \& Park, 2011) whilst transferable skills may be useful across multiple disciplines or roles (Payne, 2017). For example, teamwork, leadership or time management (Hovorka \& Wolf, 2009). Personal development skills include traits employers may seek such as self-confidence (Kent et al., 1997). However, the distinction 
provided above by Tymon (2013) suggests that these are perhaps personal attributes and, as such, may not be easily developed through education given their relationship to individuals' psychology and personality. Nevertheless, the literature provides an extensive list of skills that fieldwork might develop, and examples of these are shown in Table 1. The skills list in Table 1 is not exhaustive, and although they have all been identified as skills that fieldwork might develop, it is likely that they will not all be explicitly addressed through fieldwork. For example, students may develop teamwork or collaboration skills through activities that are technical, or subject-specific in nature (Wall \& Speake, 2012) such as working in groups to collect ecological data.

\section{*** INSERT TABLE 1 AROUND HERE***}

\section{Student perceptions of skills development}

Employers value transferable skills highly (Wakeham, 2016; Yorke, 2006), but have questioned whether graduates develop them sufficiently well during degree programmes (Sarkar et al., 2016; Thomas, 2009). Therefore, it is important that students and graduates are able to identify their transferable skills and highlight them in job applications and interviews to demonstrate clearly their suitability for a role. However, Wakeham (2016) suggests that some STEM graduates have difficulty recognising the transferable skills they have developed during their degree courses or do not understand how the skills they develop during study relate to the employment market. Several authors have shown that students do recognise skills development during fieldwork (e.g. Boyle et al., 2007; Durrant \& Hartman, 2015; Fuller, Edmondson, France, Higgitt \& Ratinen, 2006; Fuller, Gaskin \& Scott, 2003; Larsen et al., 2017; Scott et al., 2012; Wall \& Speake, 2012). However, some have also found that students often recognise fewer transferable than technical skills (e.g. Scott et al., 2012; Stokes \& Boyle, 2009; Wall \& Speake, 2012) even when the staff leading a field course thought that 
students had demonstrated the development of transferable skills. For example, Stokes and Boyle (2009) asked students what skills they thought that they had developed during a geology field course and found that most failed to recognise any transferable skills, although the authors thought students had demonstrated teamwork, time management and planning skills amongst others.

Wall and Speake (2012, p. 429) claim that students have a "clear understanding of the added employability value of fieldwork” since they recognise some of the skills they may develop through participation. However, students themselves do not often make the link between skills and their employability in the quotations presented in that paper. Similarly, Wheeler, Young, Oliver and Smith (2011) and Durrant and Hartman (2015) provide evidence of students discussing how the skills they develop through fieldwork will be useful in their futures, but it is unclear whether they are referring to future employment or continued study.

\section{The role of fieldwork and field course design in developing skills}

It is accepted that fieldwork can develop skills, but the skills students might develop may be influenced by the design of the fieldwork or field course they are undertaking. The focus of this research is fieldwork undertaken in the context of a field course though we acknowledge that fieldwork also takes place outside of this context. To distinguish between 'fieldwork' and 'field courses', we use the term 'fieldwork' to describe any activities that students may undertake in the field, whilst 'field courses' refers to multiple days of fieldwork, which build on each other (either a residential visit or multiple single days within a unit of study). Indeed, Scott et al. (2012) suggest that field courses should allow students to build on their previous learning. This might include deepening understanding of concepts that students have studied before the field course and, as such, represents an example of fieldwork contributing to a spiral curriculum as Raath and Golightly (2017) have previously stated. However, this 
process might also be followed within a field course where students build upon their learning as the course progresses. Such an iterative process may require variation in the design of fieldwork activities throughout a course.

Herrick (2010), Kent et al. (1997) and Panelli and Welch (2005) suggest that different fieldwork activities can be mapped onto two continua dependent on the levels of student participation and autonomy. This exercise results in four categories shown in Figure 1. Staffled observation represents a 'Cook's Tour' approach to fieldwork where staff give a lecture in the field (Munge, Thomas \& Heck, 2018) and the student role is mainly passive, whilst student-directed observation includes activities where students have freedom to direct their observations to features or topics of interest (Panelli \& Welch, 2005). By contrast, participatory fieldwork requires students to actively undertake data collection with the staff specifying their activity in staff-led investigations and students having responsibility for the subject and research design in student-directed investigations (Panelli \& Welch, 2005).

$$
\text { *** INSERT FIGURE } 1 \text { AROUND HERE*** }
$$

It is thought that giving students some autonomy or control over their learning can make activities more beneficial (Iversen, Pedersen, Krogh \& Jensen, 2015). When students are given autonomy, they are required to actively participate in the learning process and become responsible for the choices they make regarding the design and progress of their investigation (Iversen et al., 2015; Panelli \& Welch, 2005). Delegating this responsibility gives students the opportunity to practice skills such as planning, research design, collaboration and project management, which are employed to a lesser degree, if at all, during staff-led investigations. Furthermore, students who feel they have a sense of ownership over their activities have been shown to be more motivated both in the field (Scott, Humphries \& Henri, 2019) and university-based project work (Iversen et al., 2015). High levels of motivation have been associated with higher achievement (Lin, McKeachie \& Kim, 2003) 
and a desire to stretch oneself to learn and acquire new skills (Ryan \& Deci, 2000).

Therefore, the level of control that students have over their fieldwork may influence the skills that they are able to develop.

Previous work investigating the fieldwork-developed skills that students identify has largely asked students before or after field courses what skills they expect to develop or think they have developed (e.g. Durrant \& Hartman, 2015; Fuller, 2006; Wheeler et al., 2011). Alternatively, students with previous fieldwork experience have been asked about skills development outside of the context of a field course (e.g. Fuller et al., 2003; Wall \& Speake, 2012). These approaches ask respondents to consider a field course as a single entity, and therefore, they cannot reveal whether the pedagogical design of fieldwork within a course affects students’ perceived skill development. Consequently, whether fieldwork design influences student perceptions of skills development is unknown.

\section{Research aims and objectives}

Here, we use a novel approach to assessing student perceptions of skills development by asking participants to reflect on their experiences at least once on each day of a field course, as engagement with, and reflection on, one's experiences is suggested to help make personal development explicit (Ballantyne, Anderson \& Packer, 2010; Blair, 2011; Blair \& Deacon, 2015). This method allowed us to investigate whether different designs of fieldwork activities throughout a field course influenced the skills that students thought they developed. The fieldwork designs were staff-led and student-directed, which correspond with the categories of fieldwork introduced in Figure 1. In the staff-led fieldwork, staff (university lecturers supported by postgraduate student demonstrators) defined the investigations and specified the data that students collected. In student-directed fieldwork, students were responsible for suggesting, designing and undertaking their own ecological field investigations, the results of 
which were submitted as written reports for the module assessment. Our work addresses a need identified by Fuller et al. (2006) to understand how different types of fieldwork prepare students for employment and our findings will help to inform best practice in field course design for maximum student benefit. The specific questions we sought to address were:

(1) Does the fieldwork design - staff-led or student-directed - affect the skills that students identify?

(2) Do students recognise the potential enhancement to their employability from skills developed through fieldwork?

\section{Methods}

\section{Student participants and field courses}

Data were collected from 61 final-year undergraduate bioscience students in the School of Environmental Sciences at the University of Hull. The University of Hull is an English pre1992 university with over 16,000 students. All participants had chosen the optional final-year undergraduate module 'Field Studies' and were enrolled on a range of BSc degree programmes including Biology, Zoology, Marine and Freshwater Biology and Ecology. Participation in the research was voluntary and all participants provided informed consent in line with the ethical approval, which was granted by the School of Environmental Sciences at the University of Hull (approval code H010). The field courses took place during the 2017 summer break prior to the final year of the degree.

The students were undertaking a field course at one of three destinations offered in the Field Studies module: Malaysia (22 students), Spain (20 students), and the UK (19 students). Thirteen of the 61 participants (21\%) were mature students and there were slightly more female $(51 \%, n=31)$ than male students $(46 \%, n=28)$. Two students preferred not to state their gender $(<3 \%)$. The three courses differed in length (Figure 2), but as they were options for 
the same module, all followed the same format and had the same learning objectives, which were achieved through the investigation of local environments. The content of the courses differed as did the field techniques taught during the courses; for example, Malaysia was a scuba diving field course, in Spain, there was a focus on Mediterranean ecology and the UK course had a focus on techniques that graduates might require in job roles related to UK ecology. In all cases, the field techniques taught were dictated by the local habitats and organisms. The first part of each of the courses comprised staff-led field-based learning activities. Each staff-led day featured participatory fieldwork where the students learnt about the sites that they were visiting, practised appropriate fieldwork techniques and collected data to investigate aspects of the ecology of the site. Following the staff-led investigations, students identified a question of interest and worked in small groups to design and conduct their own investigations using the knowledge and techniques they had learnt during the staffled part of the course. The individual trip structures are shown in Figure 2.

\section{*** INSERT FIGURE 2 AROUND HERE***}

\section{Data Collection}

Data to assess students’ skills development perceptions were collected using a fieldwork skills diary. On the Malaysia field course, the diary questions were included in the field notebook students were required to complete for the module assessment and students completed an entry for each dive (two per day). Students on the Spain and UK field courses also completed field notebooks, but these students were provided with a separate skills diary

and were asked to complete an entry each day although some students completed an entry for each activity they undertook, which sometimes resulted in two per day. In total, students completed 460 diary entries in which answers ranged in length from a short list of skills (around 10 words) to longer explanations of the fieldwork undertaken and skills developed 
(up to 100 words).

The skills diary began by collecting some demographic information including degree course, age and gender. Each of the subsequent diary entries posed three questions, which were worded the same way on all three field courses:

(1) Can you explain what fieldwork you did today?

(2) What did you learn today, and in what activities did you learn these things?

(3) What skills did you develop today, and what helped you develop these?

The questions were purposely open to avoid drawing respondents' attention to any of the skills that fieldwork might develop. Additionally, students were not prompted about the kinds of skills that they could expect to develop when the diaries were provided. However, the module learning objectives that were shared with students included skills relating to designing and conducting field investigations safely and ethically and taxonomic identification, which could have prompted students to expect to develop these skills. The term 'skills' was not defined to students in the diaries and therefore the distinction between skills and personal attributes may not have been clear to all respondents. Nevertheless, the nature of the open questions and the lack of prompting or guidance towards particular skills when the diaries were provided should more accurately reflect the skills that students themselves consider fieldwork to develop.

Data assessing whether students recognised the potential employability enhancing nature of the skills they developed were collected using a fieldwork skills review. This questionnaire was completed at the end of the field course, after students had returned their skills diaries, and included a list of skills from the literature and the module learning objectives. Students were asked which skills they thought were the most important and how the skills and knowledge gained on the field course would be useful in their future. This latter 
question provided an insight into whether students recognised their potential importance for gaining employment. The question did not define 'the future' for the respondents, as the intention was to understand whether students independently identified that skills could be useful in their careers. Indeed, asking how students thought the skills they developed would be useful in their careers would have directed their responses and thus represented a leading question (Allen, 2017).

\section{Analysis}

The data collected to assess skills recognition were qualitative, and the analysis was both qualitative and quantitative. Firstly, the completed skills diaries were transcribed and anonymised using a randomly assigned identifier, which also included the field course destination. For example, 2017MAL01 was assigned to the first respondent on the Malaysia field course in 2017. We used thematic analysis (Nowell, Norris, White \& Moules, 2017) to identify the skills students thought they had developed in their diary entries. Thematic analysis was chosen as this is a flexible approach that can provide a detailed explanation of a data set (Braun \& Clarke, 2006; Nowell et al., 2017). Therefore, this approach was suitable for both short diary entries where students simply listed skills and longer entries where they explained in more detail their experience and how their skills had developed. Initially, codes describing the skills mentioned in the diary entries were generated inductively from the data and recorded on the transcripts using NVivo qualitative analysis software (QSR, 2015). The inductive approach was used as this research seeks to understand the skills that students independently identify and therefore, it was appropriate that the codes were generated from the responses provided by the students. Furthermore, Braun and Clarke (2006) and Nowell et al. (2017) suggest that initial codes should be generated from the data. 
Diary entries were coded to the skills that students identified only when their entries were worded positively and, as such, indicated that the respondent thought they had developed their proficiency in the skill concerned. In some cases, students mentioned skills in negative terms (e.g. whilst discussing issues or problems they had during the fieldwork) and such entries were not coded as evidence of development. Coding was an iterative process whereby as new codes emerged from the data, previously coded transcripts were revisited to check the accuracy of coding and apply new codes as appropriate.

Codes were initially generated by EP and the suitability of the identified codes was discussed amongst all authors. Codes were then recorded on the transcripts by EP. Following this, a subset of $10 \%$ of the diary entries $(n=46)$, selected using randomly generated numbers, were then independently checked by GS with no conferring to establish inter-coder reliability. The reliability was $99 \%$, which exceeds the target of $90 \%$ suggested by Miles and Huberman (1994). Once coding was complete, the codes were collated into themes. Three themes were initially generated deductively from the literature review. These themes were: technical skills, transferable skills and personal attributes. Codes were clustered under these themes using the definitions provided in the literature and shown in Table 1. One additional theme, 'describes skill but does not identify it as such', emerged from the data inductively and has been included. Although this theme is not directly related to the research questions, it usefully informed the analysis and implications of these results for future fieldwork teaching practice. The grouping of initial codes under parent codes and within themes was discussed and agreed by all authors. For example, 'Specific field technique’ is a parent code to the techniques listed, which are child codes. This parent code was used as there was a broad range of techniques used depending on the field course locations yet all could be grouped in this way to answer the research question and ensure the coding helpfully simplified the data for analysis (Nowell et al., 2017). The coding framework is provided in a supplementary file. 
Following the completion of the qualitative analysis, quantitative data were extracted from NVivo, which showed the number of transferable and technical skills each student identified in each diary entry. R (R Core Team, 2017) was used for all analysis and presentation of quantitative data. The numbers of skills identified in each diary entry were extracted from NVivo and included how many technical and transferable skills the students had identified in each individual diary entry alongside whether that entry related to staff-led or student-directed fieldwork. A generalised linear mixed-effects model (GLMM) was used to assess the effect of skill type (transferable or technical) and fieldwork design (staff-led or student-directed), and their interaction, on the number of skills identified per diary entry. The GLMM was used as recommended by Bolker et al. (2009) for analysing non-normal data that contains random effects. The random effect was student ID as each student completed multiple skills diary entries thus, the inclusion of this random effect eliminated pseudoreplication (Crawley, 2013). The Poisson distribution was specified as the number of skills recorded are count data (Bolker et al., 2009). To explore pairwise comparisons between the 4 possible categories, data were subsetted and additional GLMMs using the same framework were used.

However, for ease of visual interpretation, data were plotted using the mean number of skills that students identified in each of the four categories per diary entry, rather than the individual counts. This is because the courses were of different lengths and students completed different numbers of diary entries. Furthermore, all three courses had more days of staff-led fieldwork than student-directed fieldwork. Therefore, using the individual diary entries to produce the figure would not account for the differing numbers of entries by each student and for each category of fieldwork (staff-led/student-directed). 


\section{Results}

\section{Recognition of skills}

On completion of the qualitative coding, 28 skills codes had emerged from the data. Seven related technical skills and 21 to transferable skills. The skills students identified are presented in Table 2, which shows that students appeared to recognise a wider variety of transferable skills than technical skills. Additionally, eight students reported developing their professionalism, resilience, patience and independence. However, these answers were not included in the list of skills as they perhaps better represent personal attributes. Although the emerging codes showed that students identified a greater range of transferable than technical skills, the technical skill code 'specific field technique' refers to a wide range of techniques that students used and these varied depending on which field course they attended. There were 20 different techniques or skills identified by students that were coded as specific field technique and this was used 349 times making it the most frequently applied code. The coding framework in the supplementary data file shows the techniques identified by students and the definitions used for coding.

\section{*** INSERT TABLE 2 AROUND HERE***}

The second most commonly identified skill was identification or taxonomy $(n=261)$ and this was typically used multiple times by each student as all courses provided opportunities to develop identification skills using several taxonomic groups. Interestingly, it appears that not all students interpret the skill of identification in the same way. For some ( $n=8,13 \%$ ), their comments suggest that they consider they have developed the skill when they can remember the name of a species by sight. For example, two students stated 'telling one species of grass and moss by eye’ (2017UK03) and 'developed better ID skills of certain fish I recenize [sic]’ (2017MAL16). Others (n=13, 21\%) appeared to consider that identification involves the ability to use a taxonomic key to identify species e.g. 'how to 
identify and differentiate between species of grass by using a key’ (2017UK09). Thirty-two students (52\%) identified that they developed identification skills but were not specific about how they identified organisms.

Of the transferable skills students identified, teamwork was the most commonly cited $(n=57)$. The second was communication $(n=53)$ and this was frequently identified alongside teamwork in comments such as: 'Worked very well as a team, communicated well and had clear goals' (2017MAL02) and 'How to work as a group / communicate with others' (2017UK14). This is perhaps unsurprising as good communication might be considered a prerequisite for effective teamwork and it is unlikely one would highlight the development of teamwork skills if communication was poor amongst group members. Indeed, students in Malaysia highlighted examples of communication difficulties when group sizes increased: 'the plotless method is tricky to pull off in a larger dive group, as communication becomes an issue and stresses divers out' (2017MAL02). This entry was not coded as evidence of group work or communication, however, later in the trip the same student identified improvement in both skills: 'Worked very well as a team, communicated well' and the second entry was included as evidence of students identifying the development of these skills.

In some entries ( $n=29$, from 15 respondents), students appeared to describe the development of transferable skills but did not identify the skills they described. For example, one student described a plan they and their diving buddy had developed:

now me and my buddy know what to do we can go straight to a $H$. magnifica and we'll signal ... to let each other know which one of us is observing the primary or secondary first ... and then we'll swap and ... move onto the next $H$. magnifica and we will rotate until we have to ... go back to the boat. (2017MAL08)

This quotation appears to describe proficient planning, teamwork and communication, yet the respondent does not identify any of these skills explicitly and, therefore, it is unclear whether 
they recognise that they have developed these skills.

\section{Effect of fieldwork design on skills development}

There was a significant interaction between the fieldwork design and the skills students identified (Table 3; Figure 3). Pairwise comparisons showed that students identified significantly more technical skills during staff-led than student-directed fieldwork ( $\mathrm{z}=-8.392$, $\mathrm{n}=460, \mathrm{p}<0.001$ ), whereas they identified significantly more transferable skills during student-directed fieldwork ( $\mathrm{z}=649.7, \mathrm{n}=460, \mathrm{p}<0.001$ ). The model also shows that overall, students identified more technical skills than they did transferable skills (Table 3). 17 transferable skills were identified in each context, but whilst some were identified in both staff-led and student-directed fieldwork others were identified in only one of the two modes. The greatest difference was for adaptability, which was only identified in student-directed fieldwork ( $\mathrm{n}=9$ ). Many times, this related to students' independently designed fieldwork not going as they had planned. For example, where river levels were unsafe and the sampling protocol had to be adapted or where the target organism was not present about which one student stated: 'Being able to adapt to collect quantitative data is important to move forwards [sic] as a scientist' (2017MAL14). Other transferable skills that students identified more frequently during the student-directed fieldwork included planning and data collection.

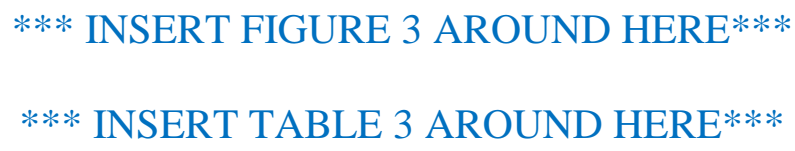

\section{Student recognition of employability enhancement}

The skills review, which assessed whether students recognised that the skills they developed on the field course could enhance their employability was completed by 55 students at the end of their course. Thematic analysis was used to code their responses to two questions, which asked how students thought the skills they had developed would be useful in their 
futures and what career they planned to pursue after graduating. The coding was undertaken by EP and the suitability of the codes and themes agreed with the co-authors. Three themes relating to usefulness emerged: non-specific usefulness, usefulness in future projects and usefulness in a career. There were nine career themes, which each related to different fields such as conservation, consultancy or teaching. Additionally, some students did not know what career they wanted to pursue, and these responses were coded as 'unknown'.

Most students ( $\mathrm{n}=48$ ) did recognise the usefulness of the skills they had developed during the field course although, of these, 16 respondents were not specific about how, when or where they would be useful. The question asked 'how' the students thought the skills would be useful, which perhaps implied that they should be useful somehow. It is possible that the responses in the theme 'non-specific usefulness' were from students who recognised this implication but were not certain how the skills would be useful to them. Indeed, these students mostly identified the skills that they thought might be the 'most' useful but did not indicate how they would be useful or how they thought they might employ these skills in the future: "I think that the critical and creative thinking I've gained will be most useful." (2017ESP06).

Other students were specific about the skills being useful for a future project $(n=7)$ and for some this project was their final year dissertation: 'My dissertation involves a bit about wetlands and so this background knowledge on them will be helpful' (2017UK11). However, some students in this group were less clear about whether the project was their dissertation or another future project: 'Better at project planning and decision making for future projects' (2017ESP01).

However, the most common response $(n=27)$ indicated that students recognised that the skills they developed during the field course would be useful in their career. Examples of responses that demonstrated this included: 
fieldwork, observation and project planning will help in future careers. Thinking on your feet to problem solve is important in any job. (2017ESP02)

I have developed my communication skills, working in a team and project management which can all be applied to future careers. (2017ESP12)

Additionally, it appears that some students recognised the transferable nature of some skills. Indeed, this was specifically highlighted by three students with statements such as: 'communication and interpersonal [skills] will be useful in any job. Same with presentation' (2017ESP13).

Where students identified which skills they thought would be most useful for their careers they cited technical and transferable skills a similar number of times: 15 and 16 respectively. However, the transferable skills that were recognised were often framed in a subject-specific context:

Fieldwork, critical thinking and adapting to new situations as I intend to work in field biology in the future, and these aspects are vital in order to remain flexible in response to an unpredictable natural environment (2017UK07)

This might reflect the overwhelming intention of students to seek a career related to their degree. Indeed, of the 55 students who completed the skills review, 41 planned to seek a career related to their degree in some way with the most common responses being a career in conservation $(n=13)$ or research $(n=9)$.

\section{Discussion and implications for practice}

\section{Recognising skills and their value}

Our data demonstrate that the teaching design of fieldwork can affect the skills that students are able to develop and recognise. The inclusion of student-directed fieldwork following the staff-led fieldwork on the courses studied here appears to have allowed students to acquire 
and recognise a wide range of transferable skills additional to the technical skills they developed. Indeed, the data show that when participating in the student-directed fieldwork, students identified more transferable skills than they did in staff-led fieldwork. This suggests that when students are given more control over or responsibility for defining their tasks, they are able to develop a greater variety of transferable skills.

It is also possible that the design of the field courses, with staff-led fieldwork preceding student-directed fieldwork, caused the differences in skills development that we found. For example, Peacock, Mewis and Rooney (2018) suggest that increased familiarity with a field environment reduces the cognitive load on students by decreasing the amount of new information, which in turn allows students to concentrate on developing skills. Indeed, students may have become sufficiently familiar with field sites and techniques during the staff-led fieldwork that when given the opportunity to undertake their own investigations a reduced cognitive load allowed them to develop additional skills. However, one could also argue that delegating the responsibility for designing the investigations to the students once again increased the cognitive load as planning an appropriate and robust ecological field investigation may have been novel to many students and was certainly novel in this field course. It is difficult to isolate the impact of sequence as the staff-led component of the field course was necessary to introduce students to the environments and techniques available for the student-directed work. This approach is common to many field courses; Panelli and Welch (2005) suggest that fieldwork training is necessary before increasing student autonomy and Scott et al. (2012) suggest that the best field courses are iterative whereby students are given the opportunity to use past experiences to inform their future practice. Furthermore, Harmer and Stokes (2016) showed that students value relevant training before being given tasks with high levels of autonomy. 
There is evidence, however, to support the assertion that the increased autonomy that was characteristic of the student-directed fieldwork mediates the development of transferable skills. Indeed, the delegation of the responsibility for the design and progress of the studentdirected investigations requires students to employ additional skills such as, planning and risk management, which are largely the responsibility of the leaders during the staff-led fieldwork. Additionally, as Scott et al. (2019) showed, students who feel that they have ownership of their fieldwork through increased levels of autonomy are more motivated, which Ryan and Deci (2000) suggest in turn encourages them to strive for learning and skills development. This process is grounded in self-determination theory, which posits that autonomy is one of three needs, along with relatedness and competence, that underpin optimal personal development (Ryan \& Deci, 2000). In the context of skills development, self-determination theory suggests that when students have defined their own goals, and are motivated to achieve them, then they might gain transferable skills as a result of working towards their goal. Indeed, in other domains, increased student autonomy has been shown to develop transferable skills. For example, in adventure education, Sibthorpe, Paisley, Gookin and Furman (2008) reported greater leadership and outdoor skills development in students involved in autonomous student expeditions, and Kavanagh, Kearns and McGarry (2015) reported that occupational therapy, physiotherapy and speech and language therapy students who completed placements in student-led clinics also reported gains in transferable skills. These included their organisational and administrative skills as they worked independently with freedom to be creative about solving problems they encountered.

Whilst our data show that the fieldwork design can influence the skills that students can acquire and recognise, we found, as others have previously (e.g. Fuller, 2006; Stokes \& Boyle, 2009; Wall \& Speake, 2012), that, overall, students identified more technical skills than they did transferable skills. Perhaps the ease with which students appear to recognise 
technical skills could be explained by the fact that these are frequently signposted to them by the tutors or course leaders. Indeed, when students learn how to use new methods or equipment this is often highlighted during the fieldwork briefing. For example, during a briefing on the UK course, students were told they would practice kick sampling and freshwater invertebrate identification and would assess water quality using the Biological Monitoring Working Party score (Paisley, Trigg \& Walley, 2014). All these skills were identified, though not by every student. Nevertheless, making explicit these technical skills may have aided students’ recognition of them. Students’ recognition of transferable skills might, therefore, be aided by highlighting or signposting both the fact that they have developed or employed a transferable skill and how this might be useful in terms of their future employability since employer’s place high value on these skills (Wakeham, 2016). Indeed, Evans, Kersh and Kontiainen (2004) suggest that transferable skills acquisition is often tacit and that learners may not recognise their development. Therefore, signposting might make clear the transferable skills that students have developed during their fieldwork. When asked how the skills they acquired during the field courses would be useful, over half of the students in our study suggested that they would be useful in their future careers. This suggests that students do recognise the employability enhancing nature of the skills they developed through fieldwork, which was previously unclear. Indeed, although Wall and Speake (2012) had claimed this was the case their respondents did not clearly identify the value of the skills they recognised in terms of employability. Where students identified which skills they thought would be most useful for their career they identified technical and transferable skills a similar number of times. However, only three students clearly articulated that they recognised the transferable nature of such skills, which perhaps reflects the assertion of Wakeham (2016) that students have difficulty mapping their skills onto the job market. Indeed, although students identified that the skills would be useful in 
their careers our methods do not reveal whether they might use examples from their fieldwork participation to demonstrate their skills when seeking employment.

\section{Maximising skills development and recognition}

It is likely that staff-led fieldwork will be necessary for at least part of a field course to introduce students to the environment(s) of interest and the appropriate skills for undertaking fieldwork there. However, our data suggest that the inclusion in a field course of studentdirected fieldwork in addition to staff-led activities may maximise the skills that students could develop. For example, on the UK field course, students conducted staff-led fieldwork surveying freshwater habitats, vegetation, soils, small mammals and bats. Collectively, these activities provided opportunities to develop a variety of technical skills, whilst the studentdirected investigations were more focused and consequently, required fewer technical skills. The focus of the student-directed investigations was determined by the students' interests and employed or built upon the skills and knowledge students had gained during the staff-led fieldwork. Therefore, students’ own investigations employed technical skills they had practised early in the field course. However, the student-directed fieldwork also allowed students to develop transferable skills that the staff-led fieldwork did not. For example, being able to adapt when their fieldwork did not go according to plan, project management and planning, which were reflected in students’ responses to the fieldwork skills diary. These findings reflect those of previous research that has reported students developing transferable skills when they were given greater autonomy (e.g. Kavanagh et al., 2015; Sibthorpe et al., 2008) and suggests that this phenomenon also applies in the fieldwork context.

The fact that for some skills (particularly identification) students appear to have different understandings of proficiency could impact on the perceived usefulness of their fieldwork experience in highlighting their suitability for a role. However, these different 
conceptualisations of identification skills are also present in the literature. For example, Bebbington (2005) discusses the ability of A-level students to identify common British wildflowers and assesses students by asking how many of the test species they recognise from illustrations. Goulder and Scott (2016) instead argue that the ability to identify organisms previously unknown to students is more important than the ability to recognise species. These different understandings could influence the skills that students think they have developed and have subsequent impacts on perceptions of their employability when person specifications list identification as a necessary skill. Hence, signposting skills development, as recommended above, might aid students in articulating their skills when seeking employment.

In addition to fieldwork design, our methods may also have helped students identify a wider range of skills. Stokes and Boyle (2009) comment that students in their research did not identify the transferable skills the authors thought they had developed. However, these students were asked what skills they developed after a field course and the signposted technical skills may have been more memorable to them. The act of reflecting on their skills development each day may have encouraged the students in our study to recognise a wide range of skills since they were reflecting on a smaller unit of time. Blair and Deacon (2015) employed reflective practice in fieldwork and found that an experienced fieldworker discovered that reflection provided new insight into their fieldwork practice and experience. Therefore, the inclusion of a structured and purposeful reflective exercise at the end of each day of a field course may be valuable for helping students to recognise their skills development. Indeed, a study of reflective practice in geography, environmental and earth sciences courses suggests that reflection is important for skills development (Harrison, Short \& Roberts, 2003). Furthermore, the explicit inclusion of reflection for example, in assessed 
work, as was the case for one course here, is thought to contribute considerably to students' professional development (Harrison et al., 2003).

In conclusion, field courses offer a valuable opportunity for students to develop their skills and future employability regardless of whether they wish to pursue a career related to their degree course. We suggest that to maximise these benefits, and aid students in recognising their development, field courses should incorporate a variety of fieldwork designs, which allow students to develop the widest array of skills possible. These skills should also be highlighted to students as some may have different understandings of proficiency. Furthermore, students should be encouraged to reflect on their personal development throughout a field course. Given the opportunity to do so, students in this study identified a wide range of skills and over half linked these to their future employability. It is not clear whether students do this to the extent that they might use examples from their fieldwork participation to demonstrate their employability in job applications and interviews, but future investigations might consider this.

Acknowledgements: We thank all the students who provided data for this study and two anonymous reviewers for their constructive comments on this manuscript 


\section{References}

Allen, M. (Ed.) (2017). The SAGE Encyclopedia of Communication Research Methods. Thousand Oaks, California.

Artess, J., Hooley, T., \& Mellors-Bourne, R. (2017). Employability: A review of the literature 2012 to 2016. Retrieved from York, UK: https://www.heacademy.ac.uk/knowledgehub/employability-review-literature-2012-2016

Ballantyne, R., Anderson, D., \& Packer, J. (2010). Exploring the impact of integrated fieldwork, reflective and metacognitive experiences on student environmental learning outcomes. Australian Journal of Environmental Education, 26, 47-64.

Bebbington, A. (2005). The ability of A-level students to name plants. Journal of Biological Education, 39(2), 63-67. doi:10.1080/00219266.2005.9655963

Bennett, D., Richardson, S., \& MacKinnon, P. (2016). Enacting strategies for graduate employability: How universities can best support students to develop generic skills Part A. Retrieved from Canberra, ACT: http://www.olt.gov.au/project-howuniversities-can-best-support-students-develop-generic-skills-enacting-strategiesgradua

Blair, E. (2011). Balanced reflection as a means of practitioner development in the postcompulsory education and training sector. Research in Post-Compulsory Education, 16(2), 249-261. doi:10.1080/13596748.2011.576575

Blair, E., \& Deacon, A. (2015). A holistic approach to fieldwork through balanced reflective practice. Reflective Practice, 16(3), 418-434. doi:10.1080/14623943.2015.1052388

Bolker, B. M., Brooks, M. E., Clark, C. J., Geange, S. W., Poulsen, J. R., Stevens, M. H., \& White, J. S. (2009). Generalized linear mixed models: a practical guide for ecology and evolution. Trends in Ecology \& Evolution, 24(3), 127-135. doi:10.1016/j.tree.2008.10.008

Boyle, A., Maguire, S., Martin, A., Milsom, C., Nash, R., Rawlinson, S., . . Conchie, S. (2007). Fieldwork is Good: the Student Perception and the Affective Domain. Journal of Geography in Higher Education, 31(2), 299-317. doi:10.1080/03098260601063628

Braun, V., \& Clarke, V. (2006). Using thematic analysis in psychology. Qualitative Research in Psychology, 3(2), 77-101. doi:10.1191/1478088706qp063oa

Complete University Guide. (2018). University League Tables 2018. Retrieved from https://www.thecompleteuniversityguide.co.uk/league-tables/rankings

Crawley, M. J. (2013). The R book. In (Second edition. ed.). Chichester: John Wiley \& Sons Ltd.

Department for Education. (2017). Teaching Excellence and Student Outcomes Framework Specification. Retrieved from

https://www.gov.uk/government/uploads/system/uploads/attachment_data/file/658490 /Teaching_Excellence_and_Student_Outcomes_Framework_Specification.pdf

Durrant, K. L., \& Hartman, T. P. V. (2015). The Integrative Learning Value of Field Courses. Journal of Biological Education, 49(4), 385-400. doi:10.1080/00219266.2014.967276

Evans, K., Kersh, N., \& Kontiainen, S. (2004). Recognition of tacit skills: sustaining learning outcomes in adult learning and work re-entry. International Journal of Training and Development, 8(1), 54-72. doi:doi:10.1111/j.1360-3736.2004.00196.x

France, D., Powell, V., Mauchline, A. L., Welsh, K., Park, J., Whalley, W. B., \& Rewhorn, S. (2016). Ability of students to recognize the relationship between using mobile apps for learning during fieldwork and the development of graduate attributes. Journal of Geography in Higher Education, 40(2), 182-192.

doi:10.1080/03098265.2016.1154931 
Fuller, I., Edmondson, S., France, D., Higgitt, D., \& Ratinen, I. (2006). International perspectives on the effectiveness of geography fieldwork for learning. Journal of Geography in Higher Education, 30(1), 89-101. doi:10.1080/03098260500499667

Fuller, I., Gaskin, S., \& Scott, I. (2003). Student perceptions of geography and environmental science fieldwork in the light of restricted access to the field, caused by Foot and Mouth Disease in the UK in 2001. Journal of Geography in Higher Education, 27(1), 79-102. doi:10.1080/0309826032000062487

Fuller, I. C. (2006). What is the value of fieldwork? Answers from New Zealand using two contrasting undergraduate physical geography field trips. New Zealand Geographer, 62(3), 215-220.

Furnell, J., \& Scott, G. (2015). Are we all on the same page? Teacher, graduate and student perceptions of the importance of skills thought to enhance employability. Journal of Learning Development in Higher Education(8), 1-10.

Goulder, R., \& Scott, G. W. (2016). Conflicting Perceptions of the Status of Field Biology and Identification Skills in UK Education. Journal of Biological Education, 50(3), 233-238. doi:10.1080/00219266.2016.1202489

Goulder, R., Scott, G. W., \& Scott, L. J. (2012). Students' Perception of Biology Fieldwork: The example of students undertaking a preliminary year at a UK university. International Journal of Science Education, 35(8), 1385-1406. doi:10.1080/09500693.2012.708796

Harmer, N., \& Stokes, A. (2016). "Choice may not necessarily be a good thing”: student attitudes to autonomy in interdisciplinary project-based learning in GEES disciplines. Journal of Geography in Higher Education, 40(4), 531-545. doi:10.1080/03098265.2016.1174817

Harrison, M., Short, C., \& Roberts, C. (2003). Reflecting on Reflective Learning: The case of geography, earth and environmental sciences. Journal of Geography in Higher Education, 27(2), 133-152. doi:10.1080/03098260305678

Herrick, C. (2010). Lost in the field: ensuring student learning in the 'threatened' geography fieldtrip. Area, 42(1), 108-116. doi:10.1111/j.1475-4762.2009.00892.x

Hovorka, A. J., \& Wolf, P. A. (2009). Activating the Classroom: Geographical Fieldwork as Pedagogical Practice. Journal of Geography in Higher Education, 33(1), 89-102.

Iversen, A.-M., Pedersen, A. S., Krogh, L., \& Jensen, A. A. (2015). Learning, Leading, and Letting Go of Control: Learner-Led Approaches in Education. SAGE Open, 5(4), 111. doi:10.1177/2158244015608423

Kavanagh, J., Kearns, A., \& McGarry, T. (2015). The benefits and challenges of student-led clinics within an Irish context. The Journal of Practice Teaching and Learning, 13(23), 58-72.

Kent, M., Gilbertson, D. D., \& Hunt, C. O. (1997). Fieldwork in geography teaching: A critical review of the literature and approaches. Journal of Geography in Higher Education, 21(3), 313-332. doi:10.1080/03098269708725439

Larsen, C., Walsh, C., Almond, N., \& Myers, C. (2017). The "real value” of field trips in the early weeks of higher education: the student perspective. Educational Studies, 43(1), 110-121. doi:10.1080/03055698.2016.1245604

Lin, Y.-G., McKeachie, W. J., \& Kim, Y. C. (2003). College student intrinsic and/or extrinsic motivation and learning. Learning and Individual Differences, 13(3), 251-258. doi:10.1016/s1041-6080(02)00092-4

Mauchline, A. L., Peacock, J., \& Park, J. R. (2013). The Future of Bioscience Fieldwork in UK Higher Education. Bioscience Education, 21(1), 7-19.

doi:10.11120/beej.2013.00014 
Maw, S. J., Mauchline, A. L., \& Park, J. R. (2011). Biological Fieldwork Provision in Higher Education. Bioscience Education, 17(1), 1-14. doi:10.3108/beej.17.1

McCune, V., Hounsell, J., Christie, H., Cree, V. E., \& Tett, L. (2010). Mature and younger students' reasons for making the transition from further education into higher education. Teaching in Higher Education, 15(6), 691-702. doi:10.1080/13562517.2010.507303

Miles, M. B., \& Huberman, A. M. (1994). Qualitative Data Analysis: An Expanded Sourcebook (2nd ed.). London: Sage Publications Inc.

Munge, B., Thomas, G., \& Heck, D. (2018). Outdoor Fieldwork in Higher Education: Learning From Multidisciplinary Experience. Journal of Experiential Education, 41(1), 39-53. doi:10.1177/1053825917742165

Nowell, L. S., Norris, J. M., White, D. E., \& Moules, N. J. (2017). Thematic Analysis: Striving to Meet the Trustworthiness Criteria. International Journal of Qualitative Methods, 16(1), 1609406917733847. doi:10.1177/1609406917733847

Paisley, M. F., Trigg, D. J., \& Walley, W. J. (2014). REVISION OF THE BIOLOGICAL MONITORING WORKING PARTY (BMWP) SCORE SYSTEM: DERIVATION OF PRESENT-ONLY AND ABUNDANCE-RELATED SCORES FROM FIELD DATA. River Research and Applications, 30(7), 887-904. doi:doi:10.1002/rra.2686

Panelli, R., \& Welch, R. V. (2005). Teaching Research Through Field Studies: A Cumulative Opportunity for Teaching Methodology to Human Geography Undergraduates. Journal of Geography in Higher Education, 29(2), 255-277. doi:10.1080/03098260500130494

Payne, R. J. (2017). Fieldwork is good... but why? North West Geography, 17(1), 1-11.

Peacock, J., Mewis, R., \& Rooney, D. (2018). The use of campus based field teaching to provide an authentic experience to all students. Journal of Geography in Higher Education, 1-9. doi:10.1080/03098265.2018.1460805

QAA. (2014a). Subject Benchmark Statement: Earth Sciences, Environmental Sciences and Environmental Studies. Retrieved from Gloucester:

https://www.qaa.ac.uk/docs/qaa/subject-benchmark-statements/sbs-earth-sciences14.pdf?sfvrsn=b0e3f781_12

QAA. (2014b). Subject Benchmark Statement: Geography. Retrieved from Gloucester: https://www.qaa.ac.uk/docs/qaa/subject-benchmark-statements/sbs-geography14.pdf?sfvrsn=cb9ff781_14

QAA. (2015). Subject Benchmark Statement: Biosciences. Retrieved from Gloucester: https://www.qaa.ac.uk/docs/qaa/subject-benchmark-statements/sbs-biosciences15.pdf?sfvrsn=4eef781_26

QSR. (2015). NVivo qualitative data analysis Software (Version 11): QSR International Pty Ltd.

R Core Team. (2017). R: A Langauge and Environment for Statistical Computing. Vienna, Austria: R Foundation for Statistical Computing. Retrieved from https://www.Rproject.org/

Raath, S., \& Golightly, A. (2017). Geography Education Students' Experiences with a Problem-Based Learning Fieldwork Activity. Journal of Geography, 116(5), 217-225. doi:10.1080/00221341.2016.1264059

Ryan, R. M., \& Deci, E. L. (2000). Self-determination theory and the facilitation of intrinsic motivation, social development, and well-being. American psychologist, 55(1), 68.

Sarkar, M., Overton, T., Thompson, C., \& Rayner, G. (2016). Graduate Employability: Views of Recent Science Graduates and Employers. International Journal of Innovation in Science and Mathematics Education (formerly CAL-laborate International), 24(3). 
Saunders, V., \& Zuzel, K. (2010). Evaluating employability skills: Employer and student perceptions. Bioscience Education, 15(1), 1-15.

Scott, G. W., Goulder, R., Wheeler, P., Scott, L. J., Tobin, M. L., \& Marsham, S. (2012). The Value of Fieldwork in Life and Environmental Sciences in the Context of Higher Education: A Case Study in Learning About Biodiversity. Journal of Science Education and Technology, 21(1), 11-21. doi:10.1007/s10956-010-9276-x

Scott, G. W., Humphries, S., \& Henri, D. C. (2019). Expectation, motivation, engagement and ownership: using student reflections in the conative and affective domains to enhance residential field courses. Journal of Geography in Higher Education, 1-19. doi:10.1080/03098265.2019.1608516

Sibthorpe, J., Paisley, K., Gookin, J., \& Furman, N. (2008). The Pedagogic Value of Student Autonomy in Adventure Education. Journal of Experiential Education, 31(2), 136151.

Sin, C., \& Amaral, A. (2017). Academics' and employers’ perceptions about responsibilities for employability and their initiatives towards its development. Higher Education, 73(1), 97-111. doi:10.1007/s10734-016-0007-y

Stokes, A., \& Boyle, A. P. (2009). The undergraduate geoscience fieldwork experience: Influencing factors and implications for learning. Geological Society of America Special Papers, 461, 291-311.

Tavares, O. (2017). The role of students' employability perceptions on Portuguese higher education choices. Journal of Education and Work, 30(1), 106-121. doi:10.1080/13639080.2015.1122180

The Guardian. (2018). University League Tables 2018. Retrieved from https://www.theguardian.com/education/ng-interactive/2017/may/16/universityleague-tables-2018

Thomas, C. (2009). Employability of GEES graduates: the approach of the Environment Agency. Planet(21), 21-24. doi:10.11120/plan.2009.00210021

Tymon, A. (2013). The student perspective on employability. Studies in Higher Education, 38(6), 841-856. doi:10.1080/03075079.2011.604408

Wakeham, W. (2016). Wakeham Review of STEM Degree Provision and Graduate Employability. Retrieved from https://assets.publishing.service.gov.uk/government/uploads/system/uploads/attachme nt_data/file/518582/ind-16-6-wakeham-review-stem-graduate-employability.pdf

Wall, G. P., \& Speake, J. (2012). European Geography Higher Education Fieldwork and the Skills Agenda. Journal of Geography in Higher Education, 36(3), 421-435. doi:10.1080/03098265.2011.641110

Wang, D., Zhang, G., Liu, D., \& Lai, C. (2012). Expansion of higher education and the employment crisis: policy innovations in China. On the Horizon, 20(4), 336-344. doi:10.1108/10748121211272470

Wheeler, A., Young, C., Oliver, K., \& Smith, J. (2011). Study skills enhancement through geography and environmental fieldwork. Planet, 24(1), 14-20.

Wilson, H., Leydon, J., \& Wincentak, J. (2016). Fieldwork in geography education: defining or declining? The state of fieldwork in Canadian undergraduate geography programs. Journal of Geography in Higher Education, 1-12. doi:10.1080/03098265.2016.1260098

Yorke, M. (2006). Employability in higher education: what it is-what it is not. Retrieved from York: https://www.heacademy.ac.uk/knowledge-hub/employability-highereducation-what-it-what-it-not 

Table 1. Examples of skills that could be developed through fieldwork participation. (Compiled from: France et al., 2016; Goulder et al., 2012; Hovorka \& Wolf, 2009; Kent et al., 1997; Larsen et al., 2017; Mauchline et al., 2013; Maw et al., 2011; Wall \& Speake, 2012; Wilson, Leydon \& Wincentak, 2016)

\begin{tabular}{|c|c|c|}
\hline Technical skills & Transferrable skills & Personal development \\
\hline $\begin{array}{ll}\text { Field skills } \\
\text { - } & \text { Identifying organisms } \\
\text { - } & \text { Using standard survey } \\
\text { methods e.g. Phase I/ } \\
\text { NVC/Kick Sampling } \\
\text { - } \quad \text { Describing soil profiles } \\
\text { - } \quad \text { Conducting field research } \\
\text { - } \quad \text { Identifinining natural processes } \\
\text { - } \text { habitats } \\
\text { - Identifying } \\
\text { geomorphological features } \\
\text { Technical information } \\
\text { management } \\
\text { - } \text { GPS use } \\
\end{array}$ & $\begin{array}{ll}\text { Working with others } \\
\text { - } & \text { Teamwork } \\
\text { - } & \text { Collaboration } \\
\text { - } & \text { Communication } \\
\text { - } & \text { Leadership } \\
\text { Project processes and } \\
\text { organisation } \\
\text { - } \quad \text { Project management } \\
\text { - } & \text { Planning } \\
\text { - } & \text { Research design } \\
\text { - } & \text { Data collection } \\
\text { - } & \text { Data management } \\
\text { - } & \text { Data analysis } \\
\text { - } & \text { Presentation } \\
\text { - } & \text { Organisation } \\
\text { - } & \text { Decision making } \\
\text { - } & \text { Time management } \\
\text { Generic skills } \\
\text { - } & \text { Reflection } \\
\text { - } & \text { Problem-solving } \\
\text { - } & \text { Critical thinking } \\
\text { - } & \text { Observation } \\
\text { - } & \text { Adapting to new situations } \\
& \text { knowledge } \\
\text { opracy/mathematics } \\
\text { - }\end{array}$ & $\begin{array}{l}\text { Self-management } \\
\text { Interpersonal/social skills } \\
\text { Building confidence } \\
\text { Environmental respect }\end{array}$ \\
\hline
\end{tabular}


Table 2: The skills that students identified in diaries and the frequencies with which they were identified.

\begin{tabular}{|c|c|c|c|c|}
\hline Technical Skills & \multicolumn{4}{|c|}{ Transferable Skills } \\
\hline 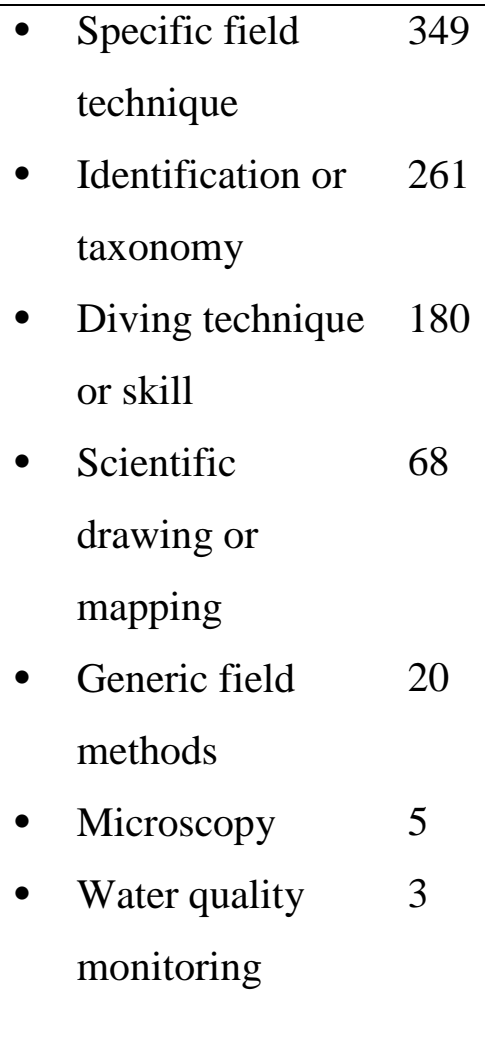 & $\begin{array}{ll}\text { - } & \text { Teamwork } \\
\text { - } & \text { Communication } \\
\text { - } & \text { Planning or } \\
\text { - } & \text { Datganisation collection } \\
\text { - } & \text { Observation } \\
\text { - } & \text { Numeracy or } \\
\text { - } & \text { Improvistics } \\
\text { - } & \text { Risk or hazard } \\
\text { - } & \text { Time } \\
& \text { management } \\
\text { - } & \text { Analysis }\end{array}$ & $\begin{array}{l}57 \\
53 \\
26 \\
21\end{array}$ & $\begin{array}{ll}\text { - } & \text { Project } \\
\text { - } & \text { } \text { Companagement } \\
\text { - } & \text { Accuracy, } \\
& \text { precision or } \\
& \text { detail } \\
\text { - } & \text { Data presentation } \\
\text { - } & \text { Multitasking } \\
\text { - } & \text { Leadership } \\
\text { - } & \text { Creative thinking } \\
\text { - } & \text { Problem-solving } \\
\text { - } & \text { Delegation } \\
\text { - } & \text { Decision making }\end{array}$ & $\begin{array}{l}5 \\
5\end{array}$ \\
\hline
\end{tabular}


Table 3: Generalised linear mixed-effects model output comparing the numbers of technical and transferable skills identified by students during staff-led and student-directed fieldwork.

Generalized linear mixed model fit by maximum likelihood (Laplace Approximation) ['glmerMod']

Fixed effects:

(Intercept)

Estimate $\quad$ Std. Error $\quad \mathrm{z}$ value $\quad \operatorname{Pr}(>|\mathrm{z}|)$

Transferable skills

$0.809 \quad 0.051$

Student-directed fieldwork

$\begin{array}{llll}-1.786 & 0.099 & -18.095 & <0.001\end{array}$

$\begin{array}{llll}-0.720 & 0.085 & -8.451<0.001\end{array}$

$* * *$

Transferable skills:student-directed

fieldwork

1.579

0.151

$-10.001$

$<0.001$ 


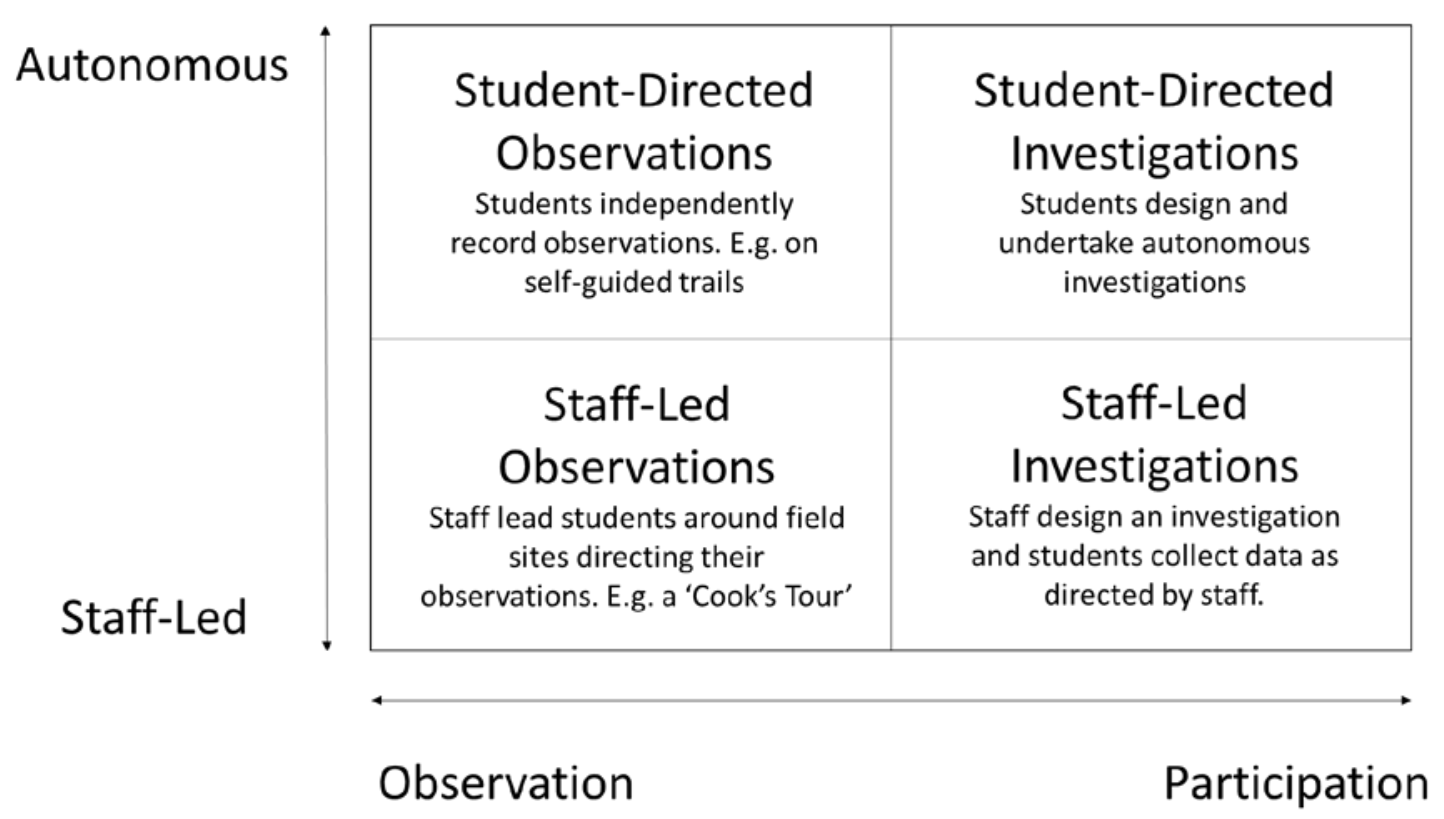

Figure 1: Categories of fieldwork activity based on the amount of control and participation that students have in the activity. (Adapted from: Herrick, 2010; Kent et al., 1997; Panelli \& Welch, 2005) 


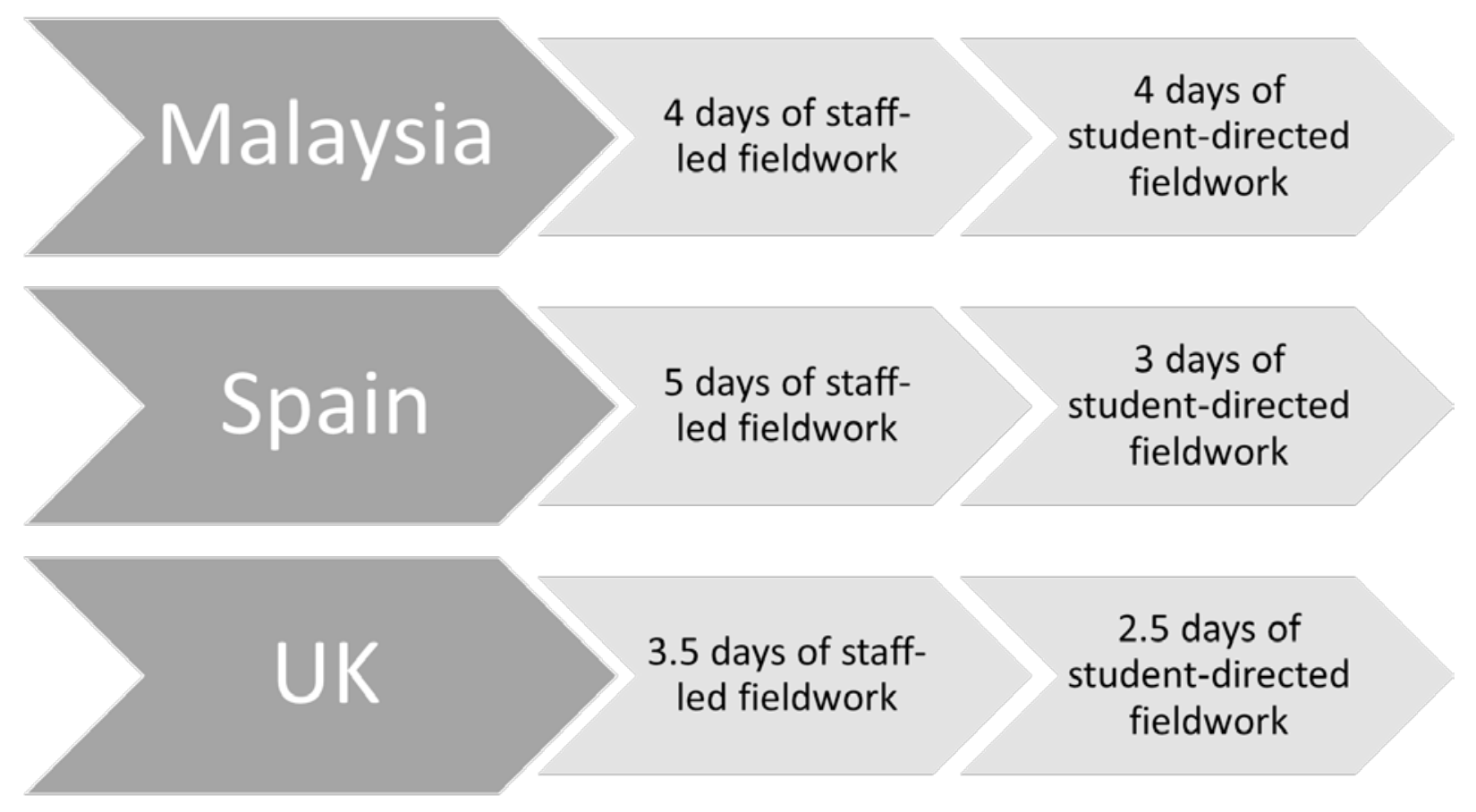

Figure 2: The structure of the three field courses where data were collected. 


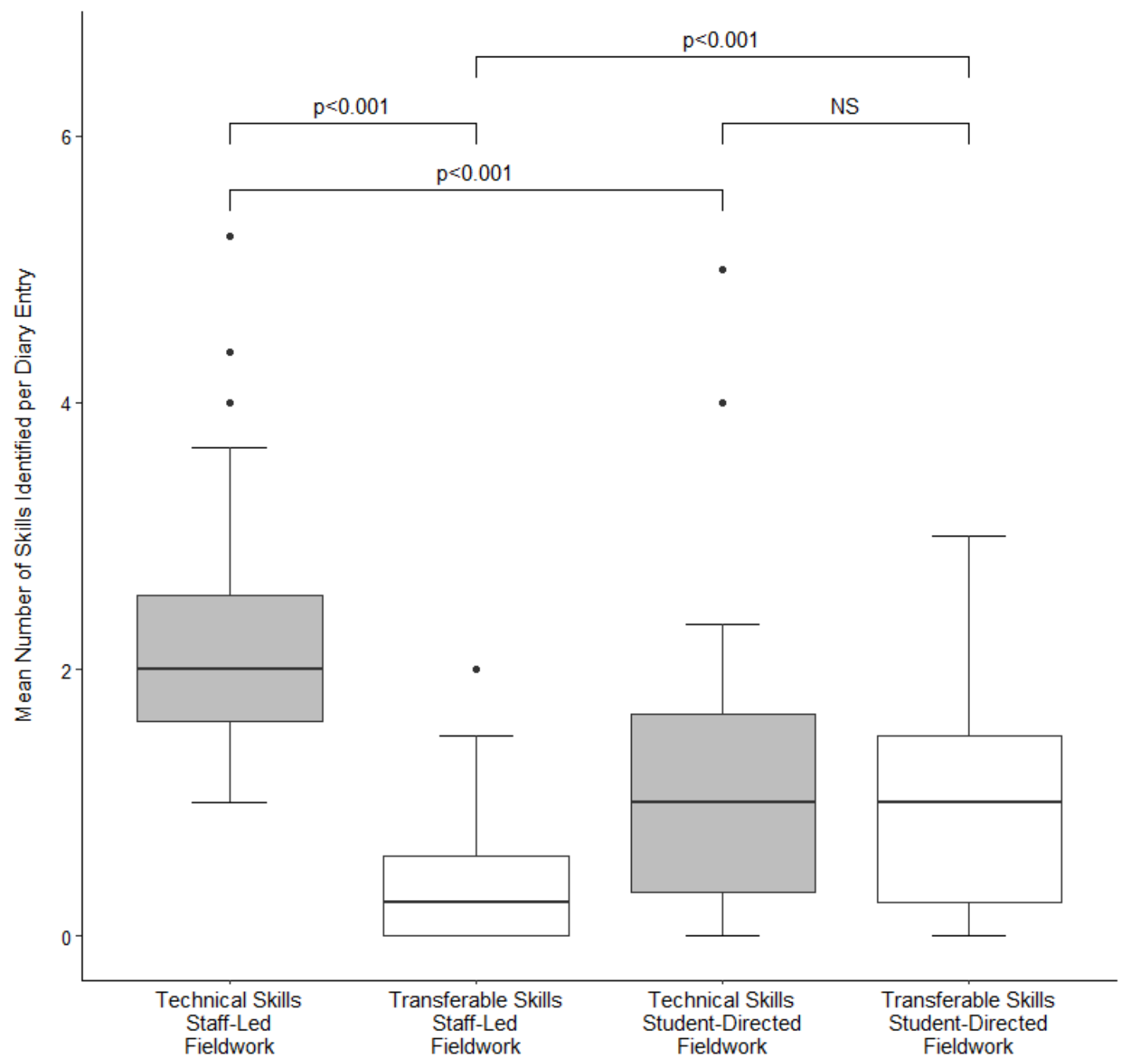

Figure 3: Numbers of technical and transferable skills identified by students during staff-led and student-directed fieldwork. 
Figure 1: Categories of fieldwork activity based on the amount of control and participation that students have in the activity. (Adapted from: Herrick, 2010; Kent et al., 1997; Panelli \& Welch, 2005)

Figure 2: The structure of the three field courses where data were collected.

Figure 3: Numbers of technical and transferable skills identified by students during staff-led and student-directed fieldwork. 